\title{
E-Commerce Based on the Law of Buying and Selling in Islam
}

\section{Mohammad Yusron Sholikhin and Rachmania Nurul Fitri Amijaya}

Student of the Master Program of Science in Islamic Economics, School of Postgraduate, Airlangga University

\section{Abstract}

The digital era that is growing so rapidly affects the sales system in the world. With the industrial revolution 4.0, e-commerce is rapidly expanding to meet the needs of millennial. However, from the estimated E-Commerce sales there is less trust in E-Commerce based on sharia law. Transaction in the E-Commerce needs to be studied in Islamic law to provide a legal basis for the transaction. Many discussions need to be discussed regarding E-Commerce, starting from transactions, payment systems, producer rights, consumer rights and the law of buying and selling E-Commerce itself. This study aims to find out how the law of buying and selling contained in Islamic

Corresponding Author: Mohammad Yusron Sholikhin mohammad.yusron.olikhin2018@pasca.unair.ac.id

Received: 10 February 2019 Accepted: 14 March 2019 Published: 28 March 2019

Publishing services provided by Knowledge E

(c) Mohammad Yusron Sholikhin and Rachmania Nurul Fitri

Amijaya. This article is

distributed under the terms of the Creative Commons

Attribution License, which permits unrestricted use and redistribution provided that the original author and source are credited.

Selection and Peer-review under the responsibility of the ICIEBP Conference Committee.

\section{G OPEN ACCESS}

$\mathrm{E}$-Commerce and whether the payment system and the rights of consumers and producers are also in accordance with sharia. This study uses literature qualitative research methods with resources taken from secondary sources in the form of books, journals and rules of law relating to buying and selling. This paper uses descriptive analysis content. The results of this study indicate that Islam supports E-Commerce in order to continue to develop based on sharia principles.

Keywords: E-commerce, the law of buying and selling, Islam

\section{Introduction}

Nowadays, development is one of the phenomena that exists the rapid development of technology. This development is included in internet use in everyday life. One of the main areas that is significantly affected by the internet is the way people make transactions, business and trade in new and competitive environments (Zainul, Osman, \& Mazlan, 2004).

With the internet, human activities in buying and selling transactions have now developed with the use of electronic media. The activity of buying and selling with electronic media is often referred to as E-Commerce. Electronic commerce, or E-Commerce, is the process of buying and selling goods and services electronically with transaction 
business computers using the Internet, networks and other digital technologies (Zainul, Osman, \& Mazlan, 2004).

Furthermore, based on data, the sale of E-Commerce in Indonesia is experiencing very rapid development. The following are E-Commerce sales data from 2016 to 2017 and sales predictions from 2018 to 2022.

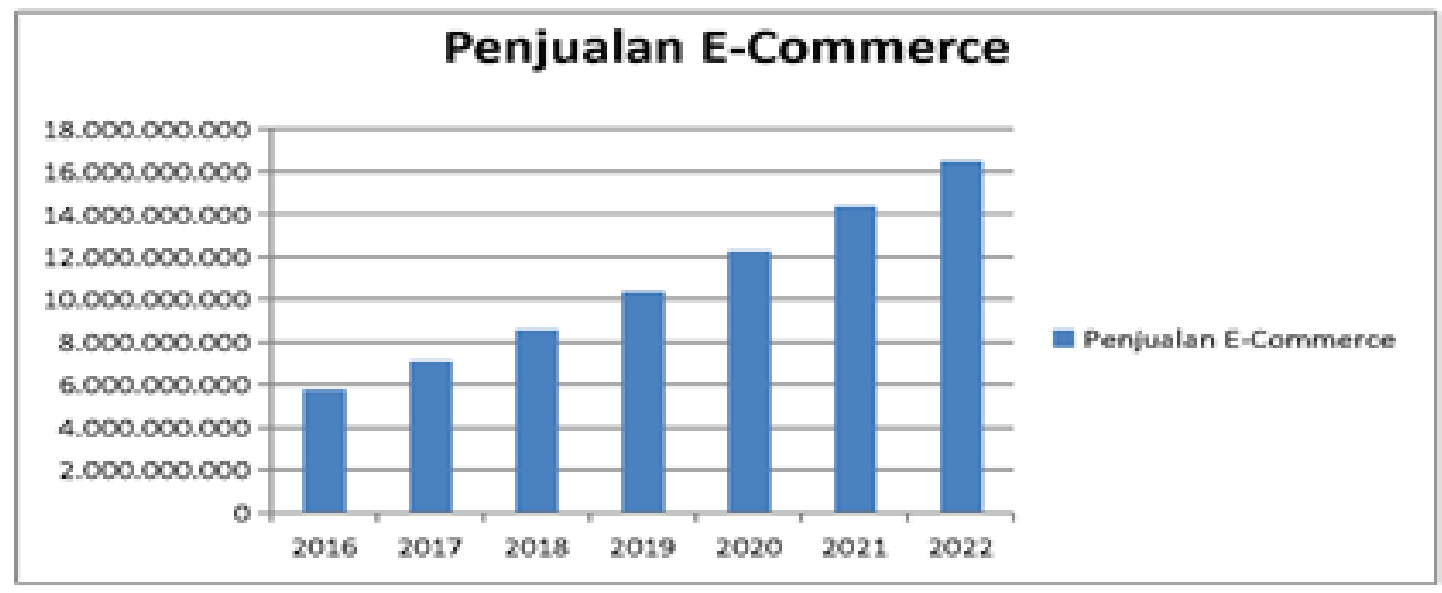

Figure 1: E-Commerce Sales in Indonesia (2016-2022) (Source: DATABOOKS.CO.ID)

In graph 1, it is explained that E-Commerce sales in Indonesia get results amounting to US \$ 5.8 billion in 2016 and US \$ 7.1 billion in 2017. Based on graph 1, it is also predicted that E-Commerce sales will increase until 2022 which reaches US \$ 16.5 billion. Product sales through E-Commerce in Indonesia have enormous potential in the future. However, from the huge potential of E-Commerce sales there is a problem of trust from consumers from an Islamic perspective based on sharia law (Ribadu \& Wan Ab. Rahman, 2017). It is therefore important to ensure that E-Commerce trust from a Sharia perspective is developed to encourage and meet the needs of more than 1.8 billion Muslims worldwide (Ribadu \& Wan Ab. Rahman, 2017), including over 200 million Muslims in Indonesia. Therefore it is important that the E-Commerce system must be in accordance with Islamic treaty law which requires the absence of usury, gharar, illicit objects and gambling to be permissible for Muslims (Mokhtar, Muhammad, Amboala, \& E-Alam, 2013).

Transaction contained in E-Commerce needs to be studied in accordance with the law of Islamic buying and selling in order to increase the trust of Muslims in using E-Commerce. So from that the title of this study is E-Commerce based on the law of Islamic buying and selling. Then the results of this study are expected to provide a legal basis for transactions used in E-Commerce. This study uses library research methods with data sources from books, journals and others. Then the discussion in this study 
includes business ethics on E-Commerce, payments on E-Commerce, contracts in Islam, buying and selling in Islam, and the rights of consumers and producers.

\section{Literature Review}

\subsection{E-commerce concepts}

Development of E-Commerce has experienced a variety of changes that are better every year. E-Commerce growth in recent years has also resulted in diversity and complexity in its structure and application (Zainul et al., 2004). E-Commerce refers to the use of information and communication technology to network activities and economic processes, to reduce information related to transaction costs to obtain strategic benefits (Zainul et al., 2004). Based on the research conducted (Kwak, Zhang, \& Yu, 2018) as a whole Alibaba has become a business leader who has created "standards" in doing business and industrial development in the Chinese E-Commerce Industry. This shows that the development of E-Commerce in other countries is also very rapid.

Based on Islamic point of view, E-Commerce has an understanding that is almost the same as conventional trade, there are several rules in E-Commerce that must be in accordance with the needs of Islamic principles and permitted by Islam. As contained in the Qur'an sura Al-Jumu'ah verse 10 which reads:

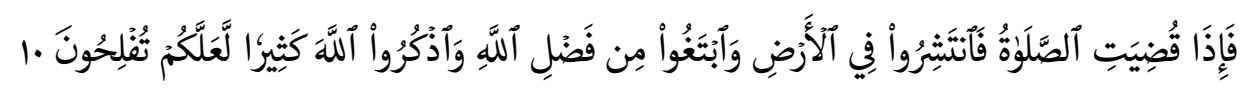

"And when the prayer has been concluded, disperse within the land and seek from the bounty of Allah, and remember Allah often that you may succeed."(Al-Jumu'ah: 10)

In this verse it is explained that Allah allows His servants to carry out any activity on earth as long as it does not conflict with Islamic principles. So in principle the use of E-Commerce is permissible as long as it does not violate or conflict with Islamic principles. From this, there are many Muslims who still doubt E-Commerce whether it is in accordance with Islamic principles.

(Ribadu \& Wan Ab. Rahman, 2017) emphasizes that many consumers distance themselves from E-Commerce because of concerns related to trust that negatively affect the risk of their online purchases. Therefore we need to know the rights that will be obtained by consumers or producers of this trust issue. The rights referred to here are rights of privacy, consumer data protection, security rights in transactions, the right to know product details, the right of producers to obtain customer information, the right to 
get payments when the product is sent and much more. Furthermore, the importance of these rights is also reflected in Al-Muthaffifiin's verse 1 which reads:

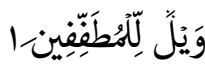

Woe to those who give less (than due). (Al-Muthaffifiin: 1)

This is intended so that there is no fraud in terms of trade so that all parties get the right accordingly. Later described also in An-Nisa 'verse 29 which reads:

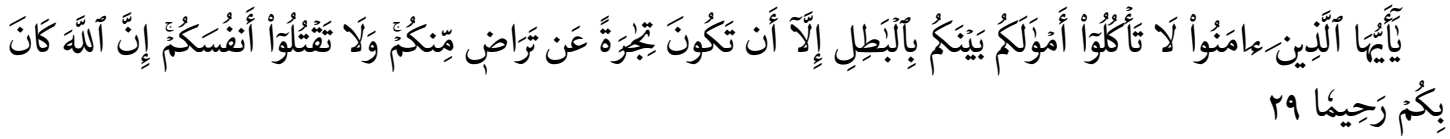

O you who believed, Do not consume one another's wealth unjustly but only (in lawful) business by mutual consent. And do not kill yourselves (or one another), indeed, Allah is to you ever merciful.(An-Nisa: 29)

Islam has arranged a sale and purchase transaction, the arrangement is included in Fiqh al-Mu'amalat. This study focuses more on the smooth running of business transactions and other commercial activities based on Islamic law. More specifically whether the values contained in the E-Commerce are in accordance with Islamic values such as honesty, convenience, contracts, speed, costs and others.

Although in E-Commerce there are various kinds of benefits, there are also problems that might arise in E-Commerce. Especially in uncertainty (Gharar), namely whether the items in the photo are in accordance with when received, then whether the goods sent will actually be sent and many more.

According to the analysis conducted by (Zainul et al., 2004) in his research, he found that Islam accepted the function of E-Commerce as a new way or technology to facilitate economic transactions. Furthermore, according to Ustadz Mustafa Omar in the study (Zainul et al., 2004) states that Islam is not against E-Commerce; on the contrary, Islam basically encourages E-Commerce as a new way of doing business. Further explained that traditionally, business is done verbally face-to-face but today both producers and consumers are connected via smartphones, computers and laptops.

In addition, (Zainul et al., 2004) the important things about approval in conducting E-Commerce is a moral perspective that leads to more responsible sellers or producers. Thus, E-Commerce in Islamic transactions must refer to Islamic principles more specifically to the law of Islamic buying and selling. Based on existing research E-Commerce is permissible in Islam, things that must be underlined are related to ethics in conducting such transactions so that there is no obscurity (gharar), and when problems occur in these transactions must be returned to existing Islamic principles. 


\section{Discussion}

\subsection{Business ethics in E-commerce}

Honesty, sincerity and trust are values that must exist in Islamic business. An entrepreneur must be honest and trustworthy in every business transaction. There is no desire to cheat, lie or promise something that is not appropriate in a business transaction. In fact, every entrepreneur is required to be able to sell his product in order to fulfil his needs. Tend to use inappropriate methods such as spreading lies so that their products sell well in the market, when advertising images and reality is not appropriate, there tends to be an exaggeration and use a psychological approach to persuade customers to buy according to their current emotional needs, not for needs the truth (Zainul et al., 2004).

The method used is very effective and puts customers more vulnerable to ECommerce transactions, because customers rely solely on information based on what is printed on the web to make purchasing decisions. Thus, customer trust plays an important role in the progress of every business matter. In An-Nisa 'verse 58 there is also an explanation of trust:

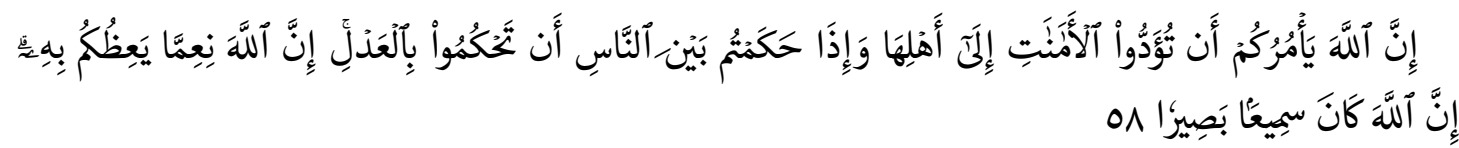

Indeed, Allah commands you to render trusts to whom they are due and when you judge between people to judge with justice. Excellent is that which Allah instructs you. Indeed, Allah is ever Hearing and Seeing. (An-Nisa: 58)

According to (Ribadu \& Wan Ab. Rahman, 2017) the most important aspect in developing the trust of shariah compliant E-Commerce trust is to ensure compliance with the requirements Islamic law contracts and avoidance of any element of usury gharar, haram and maysir which are fundamentally prohibited. Then based on research (Mertzanis, 2016) compliance with sharia or syaria compliant imposes constraints on various aspects of economic interaction, ranging from the prohibition of certain business activities to the imposition of alms. However, this can have a significant influence on behavior because of strong moral values and high religious homogeneity. Therefore the concept of trust is very important in business ethics because without trust, the development of E-Commerce cannot develop optimally. 


\subsection{Payments on E-commerce}

The issue of payment on E-Commerce is the most frequently debated thing. The problem is whether the payment method on E-Commerce is in accordance with Islamic law. There are various types of payment in E-Commerce transactions ranging from transfers, e-money payments to each E-Commerce, on-site payments via credit card. According to (Al-aaidroos, Jailani, \& Mukhtar, 2017) the method of payment using credit and debit cards has been considered a significant problem because of the possibility of usury. This is due to unspecified costs and bank interest gains taken in late payments, most Islamic jurists forbid the use of conventional credit cards.

If it is assumed that using a credit card to complete payments in E-Commerce is permissible or lawful. Halal if the customer pays all bills before the due date. However, the issue of E-Commerce is questionable when the customer only pays a minimum requirement of $15 \%$ where the issuing bank will charge a $2 \%$ monthly interest rate on the remaining balance (Zainul et al., 2004). In connection with this problem, Ustad Mustafa, argues that there is still no Islamic credit card system, it is recommended to use the murabaha system (Zainul et al., 2004).

Murabahah is defined as sales with mark-ups or costs plus profit sales. Murabahah is the (Zainul et al., 2004)sale of a product at the price at which the seller has bought it, with the addition of profits that are stated to be known by both parties namely the buyer and seller. Murabahah is used as an Islamic financing contract because it allows banks to use it as a vehicle of credit to finance buyers against pre-determined profits without taking any risks (Zainul et al., 2004).

Therefore, in E-Commerce transactions, the Murabahah system can be used as an alternative method of payment to replace a credit card.

\subsection{Islamic contract (contract) Islam}

has established a contract as an agreement from both parties to fulfil certain matters from an agreement both supply and demand. As stated in the Qur'an Surah Al-Maidah verse 1 , which means:

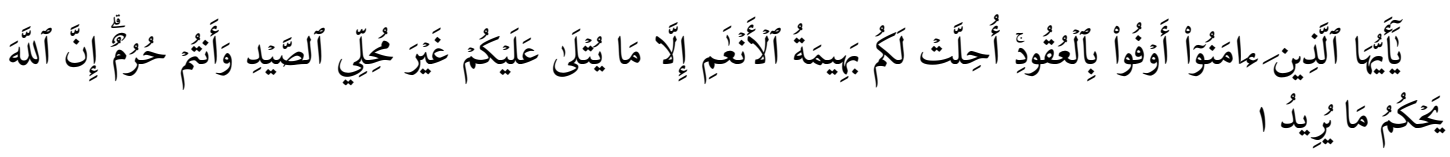

O you who believed, fulfill (all) contracts. Lawful for you are the animals of grazing livestock except for that which is recited to you (in thi Quran) - 
hunting not being permitted while you are in the state of ihram. Indeed, Allah ordains what He intends. (Surah Al-Maidah: 1)

Based on the verse, it is concluded about the principle of freedom of contract. In the concept of jurisprudence muamalah contracts are often referred to as aqad, which according to the jurists' (Islamic jurists) means the engagement between offering and accepting in ways that are prescribed and have an impact on what is assumed (AshShiddiqy, 1974). According to the school of Syafi'i, Maliki, and Hambali, defines harmony as the elements that make up the contract. According to the three schools of conduct the pillars consist of four elements, namely the parties that hold the contract (al-aqidani), the object contract (expensive al-'aql), the contract formula (sighat al-'aqd), which contains offering and accepting, while the last is the purpose of the contract (maudhu 'al-'aqd) (FORDEBI, 2017).

The contract or contract contained in E-Commerce is a legal contract that is carried out online. Because the four components are also contained in the E-Commerce contract, starting from the party that is the mind, the seller and buyer, then the contract object is the item to be purchased, then the acceptance that is done in writing and the last is the goal of contract and purchases in meeting individual needs.

\subsection{Buying and selling Islam}

There are several contracts on Islamic buying and selling related to E-Commerce. These contracts are Ba'i Al-Salam (sales ordered), Ba'i Al-Istisna '(Manufacturing Sales) and Ba'i Muajjal (Sales Suspended).

Ba'i Al-Salam in the zuhaili outbreak book is defined as the sale of something that will come in return for something now or sell something that is explained in terms of dependency (Az-Zuhaili, 2011) some pillars of Al-Salam Ba'i are offering and accepting.

Next is the istishna 'Ba'i, in terms of the jurists, istishna' is defined as a contract asking someone to make a certain item in a certain form. The point is istishna 'is the purchase of something that will be made by someone. According to the Hanafi school in the book written by the Zuhaili istishna contract 'is a contract of sale and purchase of ordered goods, not for manufacturing work. Then Ba'i Muajjal is a seller contract where both parties agree that the payment of prices for the product will be suspended (Zainul et al., 2004).

So, E-Commerce can enter into one of the three types of Islamic sale and purchase contracts mentioned above, depending on the communication model and the type of 
business being carried out. When a seller receives the first money then the newly shipped item includes Ba'i As-Salam and when a product is ordered then the payment is made after the order is called Ba'i Ishtisna'then the latter is Ba'i muajjal which is when the seller agrees to sell products to customers with prices suspended.

\subsection{The right of producers and consumers}

There are several guidelines that must be known by producers or sellers when they make transactions both traditional and electronic transactions through E-Commerce. Own production according to (Kunawangsih \& Antyo, 2006) is a process of converting various intput combinations into output. Economists define production as generating wealth through human exploitation of sources of environmental wealth. Production terminology is not found in the texts of the Qur'an or hadith. However, there are two terminologies that can be used to explain the meaning of this production, namely "alkasab" or "al-intaj" (Abidin, 2008).

The terminology of al-kasab is more appropriate to be used in Islamic economics than just a production concept. This is because the word kasab is found in verses of the Qur'an and Hadith. For example, the word of God about the obligation to issue zakat from good efforts (Al-Baqarah verse 267) and hadiths that say that there is no food eaten by someone better than the results of his efforts (kasab), actually Prophet Daud eats from the results of his own efforts (HR Bukhari).

Furthermore, kasab also means a business that with all its forms has occurred and is used in human activities every day. Since waking up to sleep again, cannot be separated from the scope of business. For instance, toiletries, clothes, furniture and so on, are the result of business processes (Arifin, 2008)

According to Al-Syaibani, as a productive business (al-iktisab), who has effort to produce wealth through means that are permissible or legalized by the Shari'a (Arifin, 2008). From the experts' explanation it can be concluded that Islamic production or sales emphasize optimizing efficiency and optimizing profits while adhering to Islamic rules or Islamic rules because the main goal is to achieve falah.

Then, after the production is accordance with Islamic law. The seller must instil aspects of honesty in order to gain customer trust. In sales through E-Commerce sellers must be honest and be able to explain to consumers what they sell, it is important to attract consumer interest and trust so as to create a reciprocal relationship that is appropriate or fair. This example of honesty is often practiced by the Prophet Muhammad. For conducting trade as when encountering one food seller in the market who keeps wet 
food under dry food so that it is not visible to the buyer. The Prophet rebuked by asking the seller to store wet food on dry food to be seen by prospective buyers, or in other words good or bad the product must be shown to prospective buyers.

According to (Qardhawi, 2000) Justice is a very crucial element, because in ECommerce transactions communication from application which is provided by seller and there is no meeting between seller and buyer. When an error occurs, people tend to designate the product producer as the culprit. Therefore, justice is an important right for producers.

Moreover, Allah commands Muslims to practice justice in the place of rights and to whom they will deal. Producers must be fair in making decisions. Similarly, producers must know their rights, such as the right to get payments when goods are sent, and the right to force consumers to buy products when they fulfill all the conditions on the initial contract that has been promised.

In addition, consumers are one of the important elements in the success of E-Commerce. Muslims must understand the technological changes that are around them, including E-Commerce. Consumers have rights that they must know and they fight for such as the right to privacy, data protection and the right to know the details of the product being sold. According to (Barkatullah \& Djumadi, 2018) legal protection for consumers is an effort to ensure certainty for consumers. With the application of law to consumers in each E-Commerce transaction, the position of consumers who previously tended to be targeted by business actors to achieve maximum profits was strengthened by State intervention, it was hoped that consumer interests in E-Commerce transactions could be protected from harmful practices.

\section{Conclusion}

To sum up, e-commerce has several things that need to be considered in terms of legal buying and selling in Islam. Islam supports the development of ways to trade through E-Commerce. However, this support must be used as well as possible because Islam supports the development of E-Commerce in accordance with Islamic law. ECommerce must consider aspects of transactions such as business ethics, payment systems, contracts, buying and selling systems and rights to consumers and producers. When this has been fulfilled, it can be concluded that based on the law of Islamic buying 
and selling, the use of E-Commerce is permissible because it can lead to benefit while still adhering to the values of Islamic buying and selling.

[1] Al-Qur'an

[2] Al-Hadits

[3] Al-aaidroos, M., Jailani, N., \& Mukhtar, M. (2017). Expert validation on a reference model for e-auctions that conform to Islamic trading principles. Journal of King Saud University - Computer and Information Sciences. https://doi.org/10.1016/j.jksuci.2017. 10.008

[4] Barkatullah, A. H., \& Djumadi. (2018). Does self-regulation provide legal protection and security to e-commerce consumers? Electronic Commerce Research and Applications, 30(May), 94-101. https://doi.org/10.1016/j.elerap.2018.05.008

[5] Kwak, J., Zhang, Y., \& Yu, J. (2018). Legitimacy building and e-commerce platform development in China: The experience of Alibaba. Technological Forecasting and Social Change, (April 2017), 0-1. https://doi.org/10.1016/j.techfore.2018.06.038

[6] Mertzanis, C. (2016). The absorption of financial services in an Islamic environment. Journal of Economic Behavior and Organization, 132, 216-236. https://doi.org/10. 1016/j.jebo.2016.10.025

[7] Mokhtar, A. H. A., Muhammad, M. Z., Amboala, T., \& E-Alam, M. S. (2013). Bai As-Salam and E-Commerce: A Comparative Analysis From Shariah Perspectives. Proceedings of the 2nd Applied International Business Conference (AIBC2013), (December), 522-529. Retrieved from http://umkeprints.umk.edu.my/2474/1/Conference2.pdf

[8] Ribadu, M. B., \& Wan Ab. Rahman, W. N. (2017). An integrated approach towards Sharia compliance E-commerce trust. Applied Computing and Informatics. https: //doi.org/10.1016/j.aci.2017.09.002

[9] Zainul, N., Osman, F., \& Mazlan, S. H. (2004). E-Commerce from an Islamic perspective. Electronic Commerce Research and Applications, 3(3), 280-293. https://doi.org/10.1016/j.elerap.2004.01.002

[10] Abidin, B. I. (2008). Revealing the Economic Thought of Classical ULama. Solo: Aqwam.

[11] Arifin, J. (2008). Is/amic Business Ethics. Semarang: Walisongo Press.

[12] Ash-Shiddiqy, H. (1974). Fiqh Muamalah. Jakarta: Bulan Bntang.

[13] Az-Zuhaili, W. (2011). Is/amic Fiqh 5. Jakarta: Gema Insani.

[14] FORDEBI, A. (2017). Islamic Economics and Business: Series of Concepts and Applications in Islamic Economics and Business. Depok: Rajawali Press. 
[15] Kunawangsih, P. T., \& Antyo, P. (2006). Basic Aspects of microeconomics. Jakarta: Grasindo.

[16] Qardhawi, Y. (2000). Norms and Ethics of Islamic Economics. Jakarta: Gema Insani Press. 